\title{
Semi-Conducting Behavior of Plio-Quaternary Basaltic Lava Flows from Hemat Madam Volcano, Sana'a-Amran Volcanic Field, Yemen
}

\author{
M. R. Eraky1*, Mohamed Th. S. Heikal² \\ ${ }^{1}$ Physics Department, Faculty of Science, Kafelsheikh University, Kafr El-Sheikh, Egypt \\ ${ }^{2}$ Geology Department, Faculty of Science, Tanta University, Tanta, Egypt \\ Email: "moharamderak@yahoo.com,mohamed.hekal1@science.tanta.edu.eg
}

Received 16 October 2015; accepted 15 December 2015; published 18 December 2015

Copyright (C) 2015 by authors and Scientific Research Publishing Inc.

This work is licensed under the Creative Commons Attribution International License (CC BY). http://creativecommons.org/licenses/by/4.0/

\section{(c) (i) Open Access}

\section{Abstract}

Electric DC and AC measurements and dielectric investigations have been carried out on some Plio-Qaternary basalt of Hemat Madam volcano from Sana'a-Amran volcanic field (SAVF). In this article we focus primarily on the field aspects and the main characteristic mineralogical and petrographic features of this inactive volcano. Using DC and AC experimental arrangements we discovered excellent electrical characteristics for this inactive volcano. The results of DC electrical resistivity versus a temperature reveal that all the samples have semiconductor characters. Moreover, the measurements showed that these samples have high resistive extrinsic semiconductors $\left(\rho_{\mathrm{DC}} \sim 10^{9} \Omega \cdot \mathrm{m}\right)$. AC and dielectric measurements were ensured the semi-conductivity and normal dielectric behavior of these samples. AC measurements reveal that the classical barrier hopping model ( $\mathrm{CBH})$ is the predominant conduction mechanism, while at low temperature region small polarons may contribute to the conduction in the samples. The samples have low values for dielectric constant $\varepsilon^{\prime}$ and low loss factor $\tan \delta\left(\varepsilon^{\prime} \sim 27\right.$ and $\tan \delta \sim 0.7$ at $200 \mathrm{~Hz}$ for the sample BA7). Then, the semicodutor behavior, the high values of DC/AC resistivity and low loss dissipation factor considered a very good characterization for magnetic semiconductor materials. So, we can predict that, the studied natural materials represent newborn promising material sciences for many more technological applications.

\section{Keywords}

Hemat Madam Volcano, Semiconductor, Basaltic Rocks, Electrical Properties

\footnotetext{
${ }^{*}$ Corresponding author.
} 


\section{Introduction}

Continental flood basalts represent some of the largest volcanic provinces at the Earth's surface. They have formed sporadically throughout the geological record with the upwelling of the hot spots [1] [2]. On the Arabian plate continental flood basalts cover an area of about 130,000 $\mathrm{km}^{2}$ throughout Yemen, Saudi Arabia, Jordan and Syria [3] [4]. The Yemen Volcanic Group on the Arabian plate and the Ethiopian Traps on the African plate lie astride the triple junction. The Yemen volcanic age is ranged from Oligocene to Plio-Qaternary [5] [6]. Generally speaking, the Yemen Volcanic Group is predominately a bimodal basalt-rhyolite province with thicknesses in excess 3500 meters, covering about 50,000 $\mathrm{km}^{2}$. Quaternary intraplate volcanism north of Sana'a (SanaaAmran Volcanic Field) covers an area of about $800 \mathrm{~km}^{2}$ (Figure 1). The Sana'a-Amran volcanic field (SAVF) is characterized by scoriaceous basalt, but they are slightly different in mineralogical composition from volcano to another one [5]. The Hemat Madam volcano is a part of Sana'a-Amran volcanic field and is located at the intersection of $15^{\circ} 30^{\prime} 8$ " lat. X $44^{\circ} 8$ '3" long (Figure 1). It covers about $1.2 \mathrm{~km}^{2}$ with altitude about $2366 \mathrm{~m}$ (a. s. l.). The materials sciences are interested with the characterization of the materials and modify their properties to become more helpful for human uses. We predict an important electrical and dielectrical character to the outcome of this volcano. So, we preferred precession to display these preliminary results of this volcano.

Our main goal of the present work gives rise to the techniques of determination of electrical and dielectrical properties of well-characterized scoriaceous basaltic rock samples. In this article we focus primarily on recent basalt from Hemat Madam Volcano. So far, to our knowledge, we think that this study represents the first time for Plio-Qaternary basalt. In the future, away from the attention of geologists, we will make a confirmatory study on these samples after grinding and adding new elements to it and sintering the samples at high temperatures, after that we will determine the same parameters in details.

\section{Material and Methods}

\subsection{Field Aspects and Petrographic Inspection}

Hemat Madam Volcano $\left(1.2 \mathrm{~km}^{2}\right)$ represents an inactive volcano of Plio-Qaternary scoriaceous basalt [5]. It constitutes a minor part of the Sana'a-Amran Volcanic Field (Figure 1). Hemat Madam Volcano is composed of cinder cone associated with vesicular lava flows and scoria-spatter cone, comprising three main rock types, from

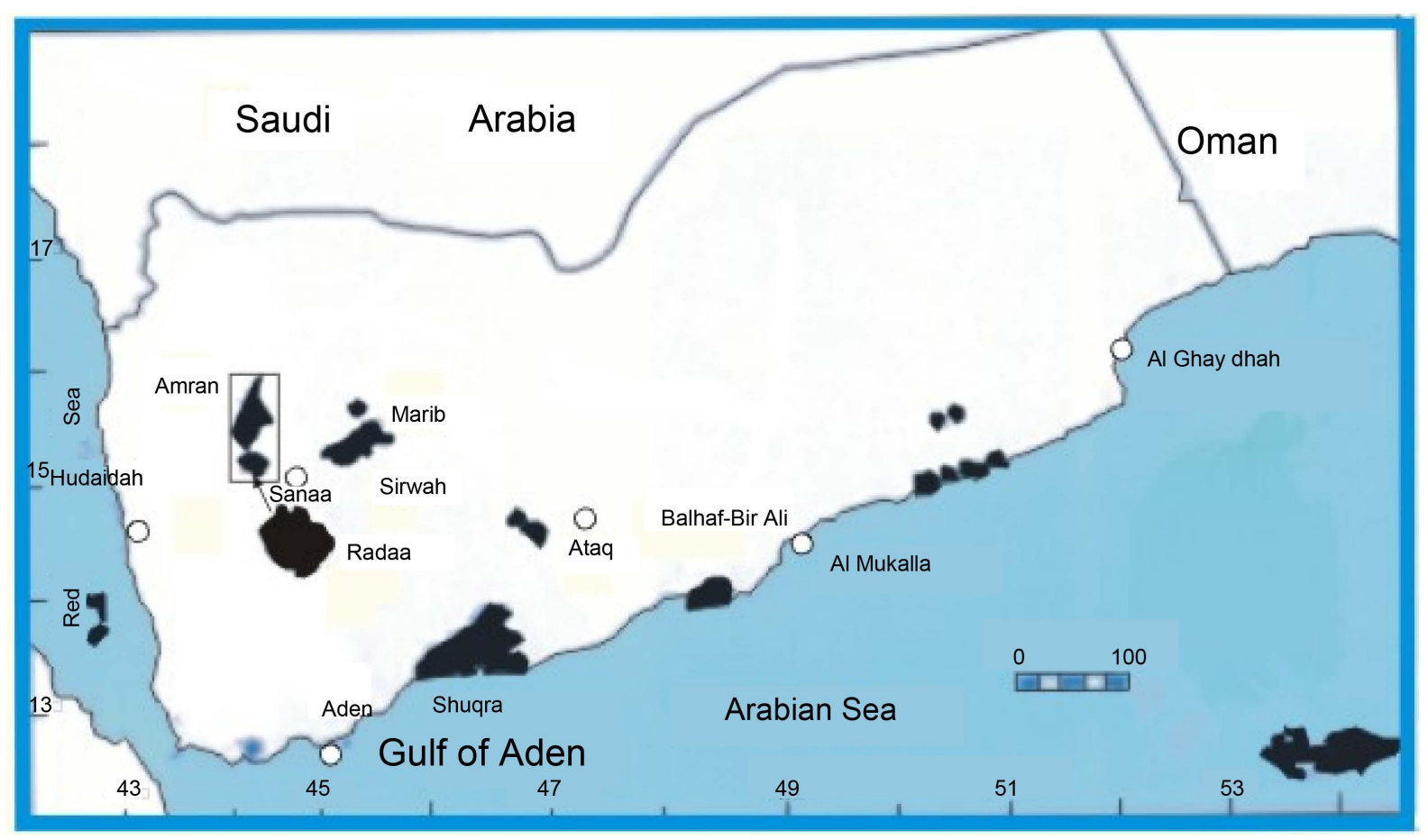

Figure 1. Location map showing the distribution of Quaternary volcanic fields of Yemen. The study area within the box is indicated by arrow. 
the foothills to top ones, namely; olivine basalt, trachybasalt and finally highly vesicular basalt at the top. The prophyritic, glassy and vesicular textures are well preserved within these rocks.

Petrographically, Vesicular basalt or scoria is a highly vesicular (Figure 2(a)). It is typically dark in color (generally dark brown, blackish gray), and basaltic in composition. The holes or vesicles tend to be rounded to subrounded-shaped. They form when gases that were dissolved in the magma come out of solution as they erupt, creating bubbles in the molten, and may form as part of a lava flow, typically near its surface. Most scoria is composed of glassy materials.

Almost olivine basalt and trachybasalt have porphyritic, glassy and vesicular textures and the phenocysts are generally rather small (less than $1 \mathrm{~mm}$ ) consisting of olivine, ca-plagioclase and clinopyroxene (Figure 2(b) and Figure 2(c)) in association with ilmenite and magnetite. The groundmass is composed of cluster aggregates of plagioclase laths and minor crystals of clinopyroxene and opaques.
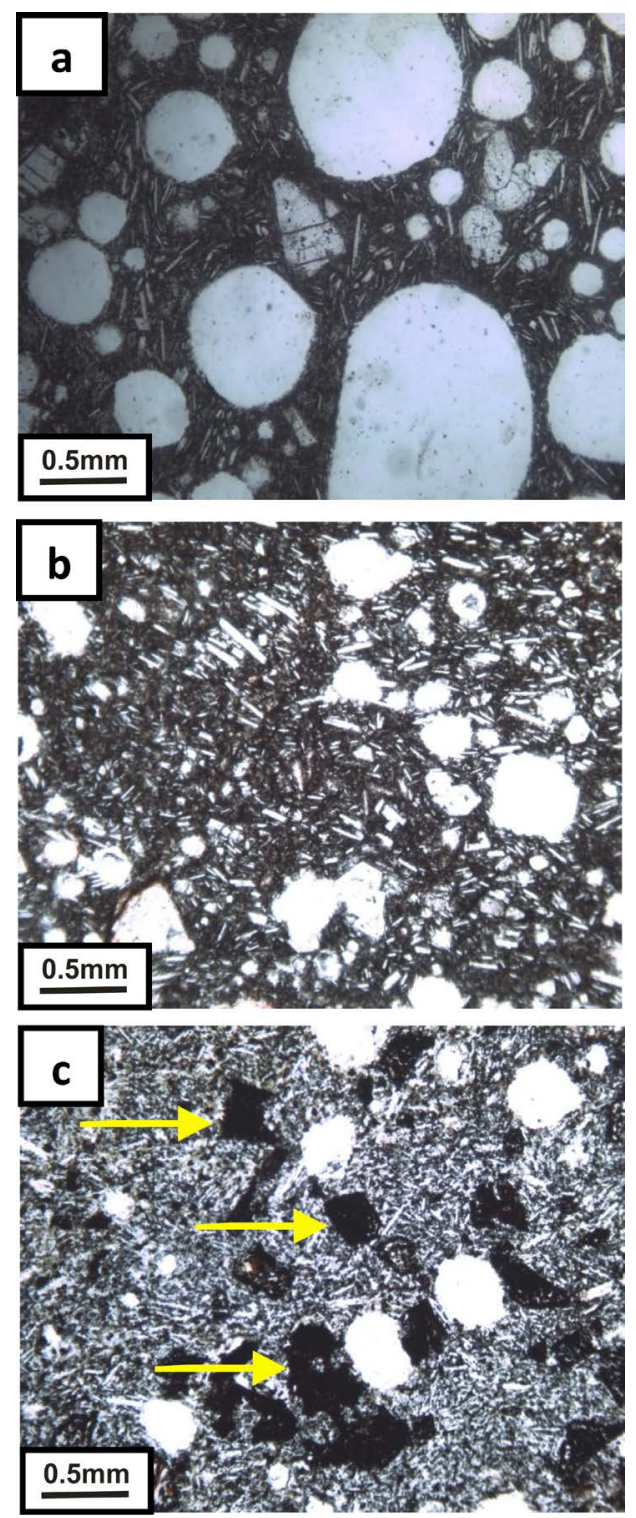

Figure 2. (a) Photomicrograph of vesicular basalt (KH1) at the top hill of Hemat Madam Volcano. Note highly rounded vesicles filled with volcanic glass. Plane polarized light; (b) Photomicrograph of trachybasalt (BH3) at the middle part of Hemat Madam Volcano. Note the flow fashion of plagioclase laths. Plane Polarized light; (c) Photomicrograph of olivine basalt (BA3) at the foothill of Hemat Madam Volcano. Note the enrichment of Fe-Ti oxide minerals (yellow arrows) throughout the rock. Plane Polarized light. 


\subsection{Preparation and Measurements}

The samples were cut in the form of a parallelogram with a thickness of $\approx 4 \mathrm{~mm}$ and dimensions of $1 \mathrm{~cm} \times 1 \mathrm{~cm}$. They were divided into 3 categories, 1) foothill of the volcano (samples BA3 \&BA7), 2) middle part of the volcano (samples BH3 \& BH9) and 3) top hill of the volcano (samples KH1 \& KH4 \& KH7). The chemical composition of the main rock-forming minerals is summarized in Table 1 . These samples were polished to obtain smooth parallel surfaces. For the DC and AC electrical measurements, the polished surfaces of the studied samples were coated with a thin layer of silver paste to ensure good electrical contact. DC electrical resistance was measured by the two probe method on the basis of Ohm's law. The resistance of the sample was determined directly by the digital electrometer (type 617 Keithley). The temperature of the sample has been determined using k-type thermocouple. AC electrical resistivity and dielectric parameters were determined by two probe method using the LCR bridge (Model HIOKI 3532-50 LCR Hi tester). The loss tangent $\tan \delta$ and the capacitance $(C)$ of the samples were recorded as a function of frequency. The dielectric constant $\left(\varepsilon^{\prime}\right)$ was calculated using the relation:

$$
\varepsilon^{\prime}=C t / \varepsilon_{0} A
$$

where $t$ is the thickness of the sample, $A$ is the area cross section of the sample and $\varepsilon_{0}$ is the permittivity of free space $\left(\varepsilon_{0}=8.854 \times 10^{-12} \mathrm{~F} \cdot \mathrm{m}^{-1}\right)$. The AC conductivity $\sigma_{\mathrm{AC}}$ of the samples was calculated from the relation:

$$
\sigma_{\mathrm{AC}}=\omega \varepsilon^{\prime} \varepsilon_{0} \tan \delta
$$

where $\omega$ is the angular frequency. AC resistivity and dielectric parameters were measured in the frequency range $100 \mathrm{~Hz}-5 \mathrm{MHz}$ at selected values of temperatures. The electrical and dielectric measurements were carried out in materials science laboratory, Phys. Dept., Fac. Science, KafrelSheikh University, Egypt.

\section{Electrical and Dielectric Results}

\subsection{Resistivity}

Figure 3 represents the variation of DC resistivity (as $\ln \rho_{\mathrm{DC}}$ ) with temperature (as 1000/T) for all the samples. It is noticed that for all samples, the electrical resistivity decreases with increasing temperature. In addition, the samples have a high DC electrical resistivity at room temperature ranged from $10^{10}$ to $\sim 10^{11} \Omega \cdot \mathrm{cm}$ (Table 2). This behavior of $\rho_{\mathrm{DC}}(T)$ for all samples is similar to the behavior of magnetic semiconductor materials, where the conductivity was activated by temperature. The outcome of the studied samples from this volcano contains many chemical components related to its rock-end products, which act as centers of production of charge carriers which contribute in conduction processes. We can suggest that the conduction in these samples may be due to the hopping of localized charge carriers between the two valence states of ions, e.g. between $\mathrm{Fe}^{3+} / \mathrm{Fe}^{2+}, \mathrm{Ti}^{4+} / \mathrm{Ti}^{3+}$ and $\mathrm{Al}^{3+} / \mathrm{Al}^{2+}$ etc. The DC electrical resistivity $\rho_{\text {DC }}$ was fitted by Arrhenius relation [7]:

$$
\rho_{\mathrm{DC}}=\rho_{o} \exp \left(E_{a} / k T\right)
$$

\begin{tabular}{|c|c|c|}
\hline $\begin{array}{l}\text { Foothill of volcano } \\
\text { BA3 \& BA7 }\end{array}$ & $\begin{array}{l}\text { Middle part of volcano } \\
\text { BH3 \& BH9 }\end{array}$ & $\begin{array}{l}\text { Top hill of volcano } \\
\text { KH1 \& KH4 \& KH7 }\end{array}$ \\
\hline Olivine basalt & Trachybasalt basalt & Highly vesicular basalt \\
\hline $\begin{array}{l}\text { Olivine, clinopyroxene, } \\
\text { Ca-plagioclase, magnetite } \\
\text { and ilmenite }\end{array}$ & $\begin{array}{l}\text { Clinopyroxene, Ca-plagioclase } \\
\text { and magnetite }\end{array}$ & $\begin{array}{l}\text { Ca-plagioclase and volcanic glass } \\
\text { (in major) and very minor } \\
\text { components of magnetite, } \\
\text { ilmenite } \pm \text { olivine and } \\
\text { clinopyroxene }\end{array}$ \\
\hline $\begin{array}{l}\text {-Olivine }=[\mathrm{Mg}, \mathrm{Fe}]_{2}\left[\mathrm{SiO}_{4}\right] \\
\text {-clinopyroxene }=\left[\mathrm{Ca}, \mathrm{Na}, \mathrm{Mg}, \mathrm{Fe}^{2+}, \mathrm{Mn}, \mathrm{Fe}^{3+}, \mathrm{Al} \text {, }\right. \\
\mathrm{Ti}]_{2}\left[(\mathrm{Si}, \mathrm{Al})_{2} \mathrm{O}_{6}\right] \\
\text {-Ca-rich plagioclase }=\left[\mathrm{Ca}, \mathrm{Na}, \mathrm{Al}_{2} \mathrm{SiO}_{3} \mathrm{O}_{8}\right] \\
\text {-Magnetite }=\left[\mathrm{Fe}_{3} \mathrm{O}_{4}\right] \\
\text { ilmenite }=\left[\mathrm{FeO} \cdot \mathrm{TiO}_{2}\right]\end{array}$ & $\begin{array}{l}\text {-clinopyroxene }=\left[\mathrm{Ca}, \mathrm{Na}, \mathrm{Mg}, \mathrm{Fe}^{2+}, \mathrm{Mn},\right. \\
\left.\mathrm{Fe}^{3+}, \mathrm{Al}, \mathrm{Ti}\right]_{2}\left[(\mathrm{Si}, \mathrm{Al})_{2} \mathrm{O}_{6}\right] \\
\text {-Ca-rich plagioclase }=\left[\mathrm{Ca}, \mathrm{Na}, \mathrm{Al}_{2} \mathrm{SiO}_{3} \mathrm{O}_{8}\right] \\
\text {-Magnetite }=\left[\mathrm{Fe}_{3} \mathrm{O}_{4}\right]\end{array}$ & $\begin{array}{l}\text {-Ca-rich plagioclase }=[\mathrm{Ca}, \mathrm{Na} \text {, } \\
\left.\mathrm{Al}_{2} \mathrm{SiO}_{3} \mathrm{O}_{8}\right] \\
\text {-volcanic glass (in major) } \\
\text {-very minor components of } \\
\text { magnetite, ilmenite } \pm \text { olivine and } \\
\text { clinopyroxene }\end{array}$ \\
\hline
\end{tabular}

\section{Table 1. Rock types under study and their mineral constituents and chemical composition of Hemat Madam Volcano.}


Table 2. DC and dielectric parameters of the studied samples at room temperature.

\begin{tabular}{cccccc}
\hline Sample & $\rho_{\mathrm{DC}}(\Omega \cdot \mathrm{m})$ & $\begin{array}{c}\rho_{\mathrm{AC}} \text { at room temp. and } \\
200 \mathrm{~Hz}(\Omega \cdot \mathrm{m})\end{array}$ & $\begin{array}{c}\varepsilon^{\prime} \\
\text { at room temp. and } \\
200 \mathrm{~Hz}\end{array}$ & $\begin{array}{c}\tan \delta \text { at RT and } 200 \\
\mathrm{~Hz}\end{array}$ & Activation energy (eV) \\
\hline BA3 & $1.95 \mathrm{E}+09$ & $4.16 \mathrm{E}+6$ & 239.88 & 6.49 & 0.57 \\
BA7 & $7.84 \mathrm{E}+08$ & $6.99 \mathrm{E}+6$ & 26.92 & 0.70 & 0.59 \\
BH3 & $7.02 \mathrm{E}+08$ & $3.51 \mathrm{E}+6$ & 28.18 & 0.62 & 0.48 \\
BH9 & $1.82 \mathrm{E}+09$ & $8.80 \mathrm{E}+6$ & 56.23 & 1.25 & 0.57 \\
KH1 & $1.68 \mathrm{E}+09$ & $2.30 \mathrm{E}+6$ & 33.88 & 2.03 & 0.52 \\
KH4 & $8.41 \mathrm{E}+08$ & $1.39 \mathrm{E}+7$ & 208.93 & 2.00 & 0.67 \\
KH7 & $2.03 \mathrm{E}+09$ & $3.20 \mathrm{E}+7$ & 52.48 & 1.91 & 0.42 \\
\hline
\end{tabular}

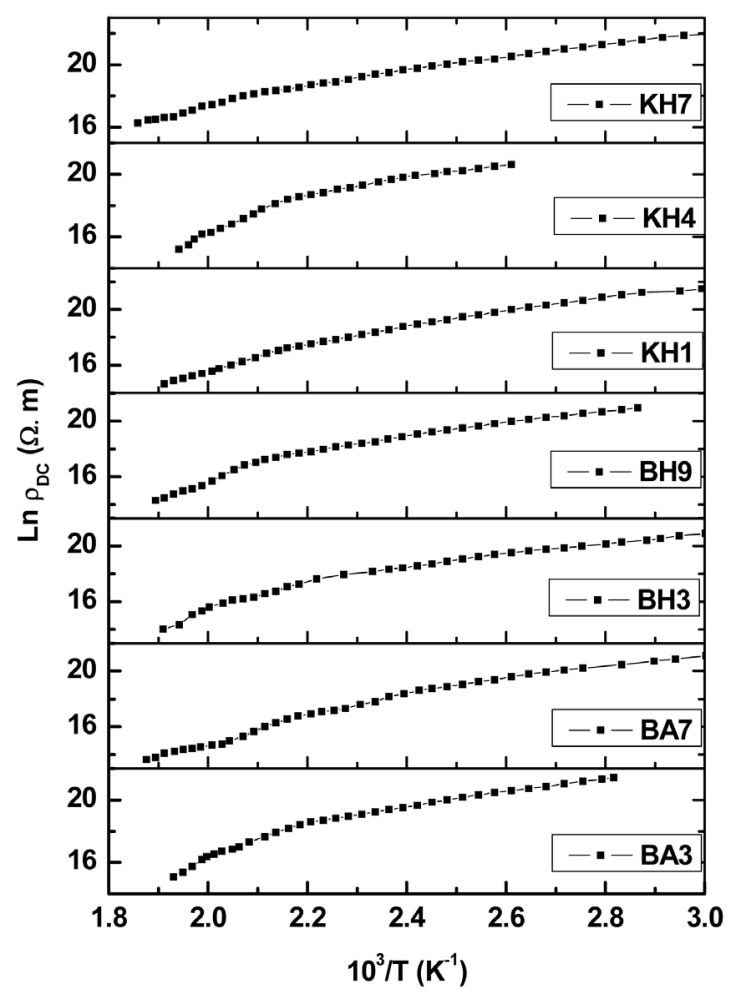

Figure 3. The variation of DC resistivity $\left(\ln \rho_{\mathrm{DC}}\right)$ vs. temperature $(1000 / \mathrm{T})$.

where $\rho_{\mathrm{DC}}$ is a pre-exponential constant, $T$ is the absolute temperature, $k$ is Boltzmann's constant and $E_{a}$ is the activation energy for conduction. The activation energy for the conduction for all samples were calculated using Equation (3) and given in Table 2. It is noticed that the values of the activation energy range from 0.42 to $0.67 \mathrm{eV}$ for all the samples which mean that these samples have an extrinsic semiconductors character. The high values of the activation energies are larger than $0.3 \mathrm{eV}$. These results according to Purushotham [8] and Klinger [9] suggest that in addition to the hopping of charge carriers between valence states of ions in the sites the Polaron hopping shares in the conduction process too. The high resistivity and extrinsic semi-conductive behavior of the studied samples tend to be a newborn important character for more technological applications when low eddy current semiconductor materials are required.

\subsection{AC Electrical Resistivity}

The frequency dependence of AC resistivity at room temperature is displayed in Figure 4 as a ln-log scale. The 
figure reveals that the values of AC resistivity decrease as the frequency of applied electric field increases.

$\mathrm{AC}$ resistivity was recorded as a function of frequency at selected temperatures. Figure 5 represents an example for the dependence of $\rho_{\mathrm{AC}}$ on the temperature at the selected frequency for BH3 sample. This behavior for AC resistivity confirm the semiconducting character for the samples. The AC conductivity of the semiconductor samples can be written as a power law relation:

$$
\sigma_{\mathrm{AC}}(\omega)=B \omega^{s}
$$

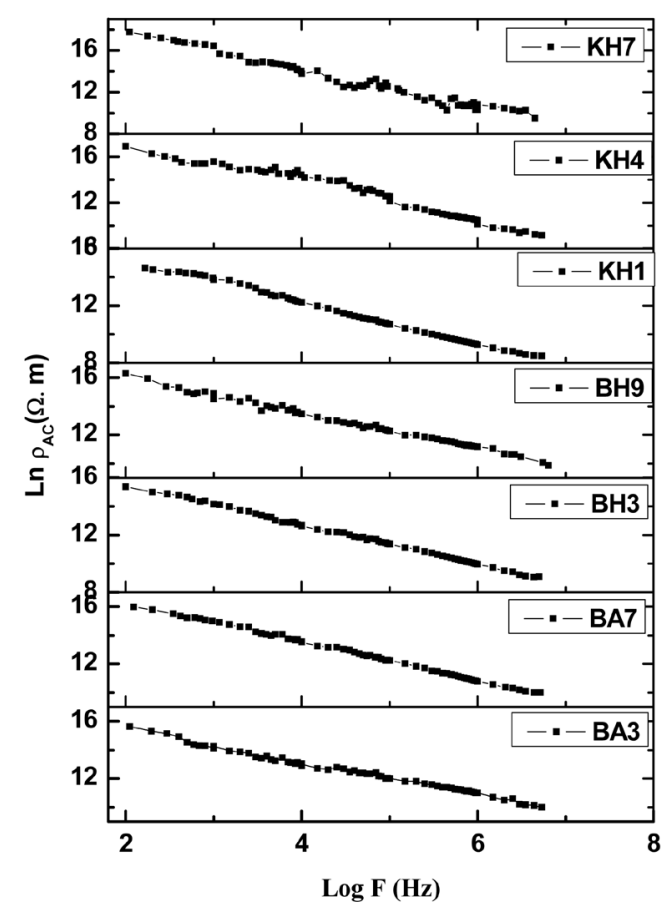

Figure 4. The frequency dependence of AC resistivity $\left(\ln \rho_{\mathrm{AC}} \mathrm{vs} . \log \mathrm{F}\right)$ at room temperature for all the samples.

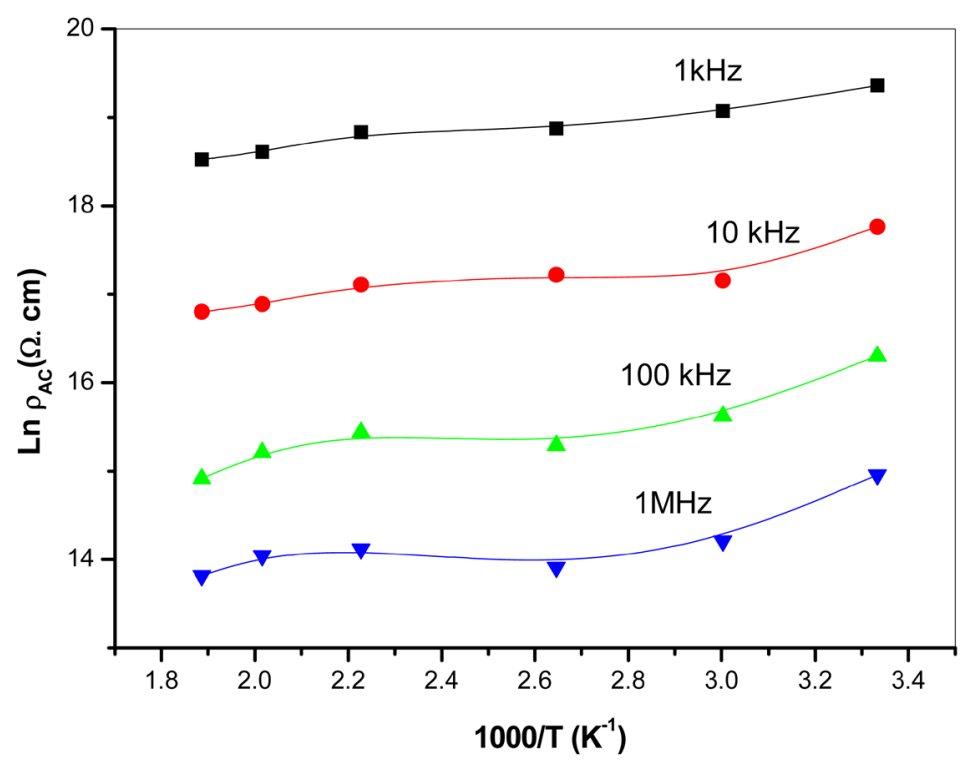

Figure 5. The temperature dependence of AC resistivity ( $\ln \rho_{\text {AC }}$ vs. 1000/T) for the sample $\mathrm{BH} 3$ at fixed frequencies. 
where $\omega$ is the angular frequency, $B$ is a constant having the unit of the conductivity and $s(T)$ is a dimensionless parameter dependent on the temperature and has a value between 0 and 1 . The AC conduction mechanism can be predicted from the magnitude of the power (s) as a function of temperature. According to the above equation, the angular frequency parameter (s) was determined from AC conductivity as a function of frequency $\left(\ln \sigma_{\mathrm{AC}}=\ln \right.$ $\left(1 / \rho_{\mathrm{AC}}\right)$ vs. $\left.\ln f\right)$. Figure 6 shows the behavior of (s) with the temperature for all the samples. It is reported that the dependence of $\mathbf{s}$ on temperature is a function of the conduction mechanism [10]. Small polarons are usually associated with an increase in s with increasing temperature, while the classical barrier hopping model (CBH) predicts the hopping of localized charge carriers over the barrier when (s) decreases with temperature. From the obtained data, it is suggested that in the low temperature region small polarons may contribute to the conduction, while at higher temperatures classical barrier hopping model CBH may predominate. From Figure 6 we can notice that for sample KH7 the principle conduction mechanism depends on CBH at all temperature range [10] [11].

\subsection{Dielectric Behavior}

The dielectric constant characterizes the most important electrical property of the dielectrics. The dielectric constant (or relative permittivity) $\varepsilon^{*}$ of a dielectric material placed in the AC electric field is a complex quantity because the orientation polarization lags behind the polarizing electric field as the frequency of the applied electric field is increased. The complex dielectric constant $\varepsilon^{*}$ can be expressed as:

$$
\varepsilon^{*}=\varepsilon^{\prime}+j \varepsilon^{\prime \prime},
$$

$\varepsilon^{\prime}$ is the real dielectric constant which characterizes the energy stored in the dielectricmaterial, whereas the imaginary part $\varepsilon^{\prime \prime}$ represents the energy loss. The values of $\varepsilon^{\prime}$ and loss tangent tan $\delta$ at room temperature and at $300 \mathrm{~Hz}$ were inserted in Table 2. The plots of the measured $\varepsilon^{\prime}$ and $\tan \delta$ as a function of frequency at room temperature are given in Figure 7 for the samples under investigation. Both $\varepsilon^{\prime}$ and $\tan \delta$ at room temperature) decrease as the frequency increases. It is noticed that there is much decrease in $\varepsilon^{\prime}$ and $\tan \delta$ within the frequency range $0.1-1 \mathrm{kHz}$ ( 2 - 3 on an $\mathrm{x}$-scale) after that the rate of decreasing becomes smaller as the frequency increases. The decrease in $\varepsilon^{\prime}$ and $\tan \delta$ with increasing frequency indicates the formation of heterogeneous structures with the samples under investigation and this is a normal for a dielectric behavior in magnetic semiconductors [12]. It is clear that $\tan \delta(f)$ for some samples has a relaxation loss peaks at certain frequencies (samples BA7 and KH7). Such peaks were observed before in many kinds of semiconductors when the hopping frequency of the charge carriers nearly equal to that of the external electric field [13] [14]. The condition of observing dielectric loss peak can be written as $2 \pi f_{\max } \tau=1$, where $\tau$ is the relaxation time (relaxation time has an inverse proportional with hopping probability) and $f_{\max }$ is the frequency of applied electric field at maximum frequency (i.e. the peak frequency) [15].

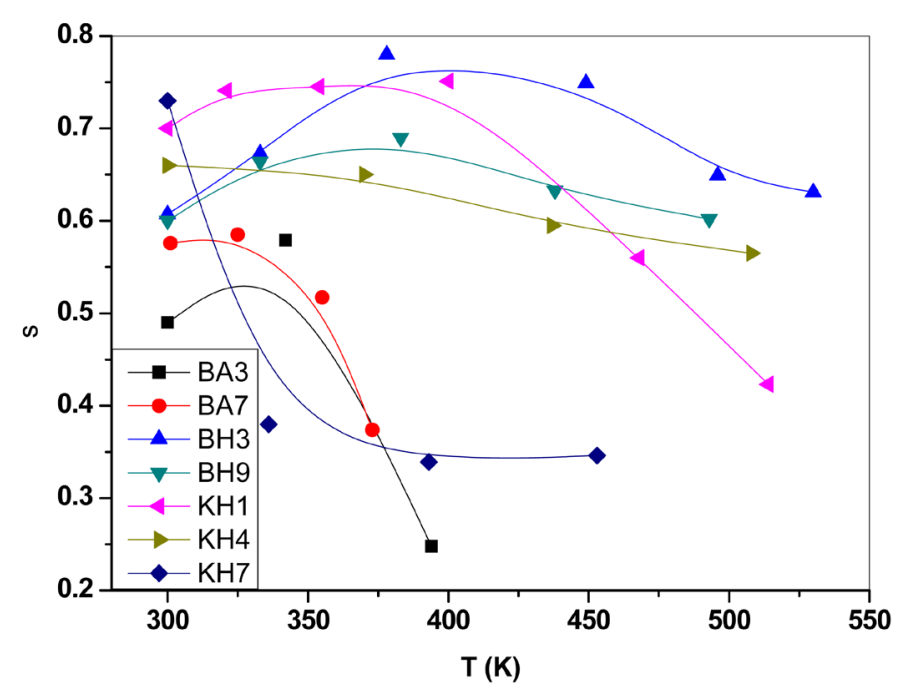

Figure 6. The variation of universal exponent (s) vs. temperature for all samples under investigations. 


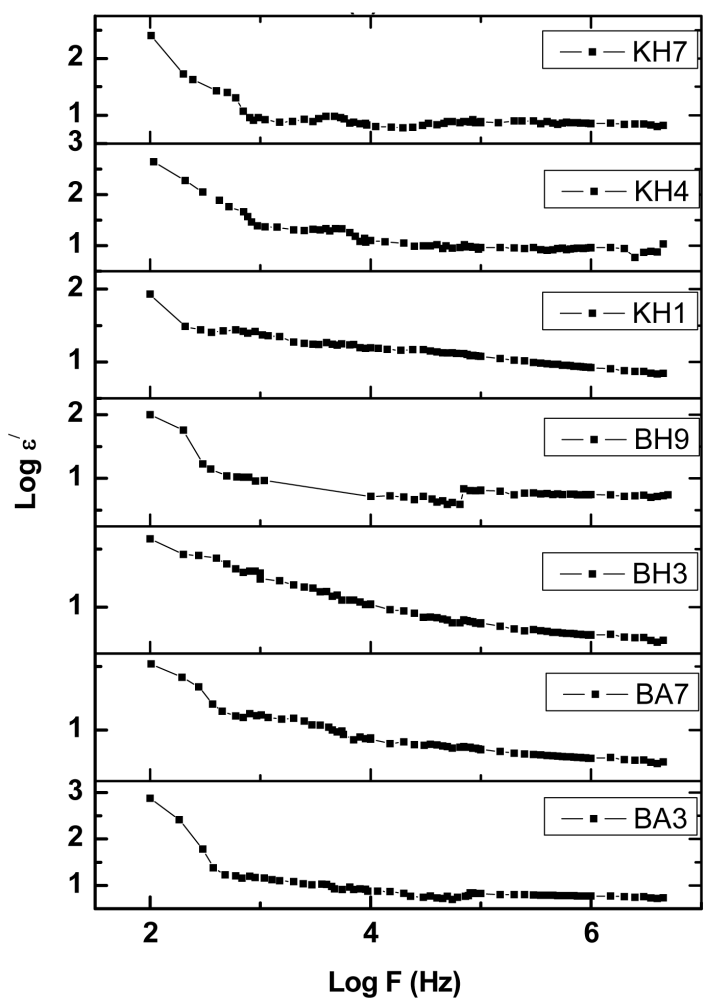

(a)

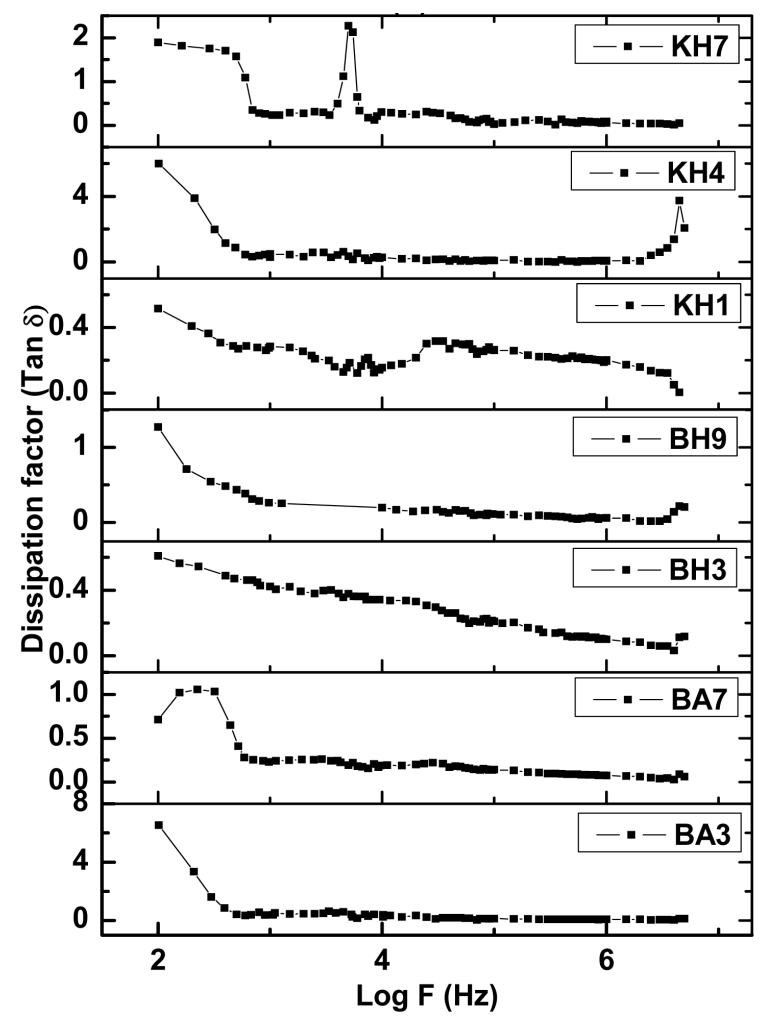

(b)

Figure 7. (a) The variation of dielectric constant $\varepsilon^{\prime}$ with frequency for all samples at room temperature; (b) The variation of the dissipation factor $\tan \delta$ with frequency for all samples at room temperature.

\section{Conclusions}

1) Electrical DC and AC measurements and dielectric investigations have been carried out on some PlioQaternary basalt of Hemat Madam volcano from Sana'a-Amran volcanic field (SAVF).

2) The temperature dependence of the DC resistivity reveals the high resistive semiconductor behavior for the samples.

3) The measurement of AC conductivity as a function of frequency and temperature ensured semiconductivity of the samples.

4) From the AC measurement data, we predicted the conduction mechanism in the samples. At higher temperatures classical barrier hopping of localized charge carriers model CBH was predominate, while at the low temperature region small polarons may contribute to the conduction.

5) The variation of dielectric constant and $\tan \delta$ with frequency reveals that the samples have low values of both $\varepsilon^{\prime}$ and $\tan \delta$ with behavior similar to magnetic semiconductor materials.

\section{Acknowledgements}

We would like to thank Prof. Dr. K. R. Mahmoud for the valuable discussions and Mr. A. Elshamy for providing some of experimental facilities during electrical measurements.

\section{References}

[1] Smith, R.B. and Braile, L.W. (1994) The Yellowstone Hotspot. Journal of Volcanology and Geothermal Research, 61, 121-187. http://dx.doi.org/10.1016/0377-0273(94)90002-7

[2] Baker, J.A., Menzies, M.A., Thirlwall, M.F. and Macpherson, C.G. (1997) Petrogenesis of Quaternary Intraplate Volcanism, Sana'a, Yemen: Implications for Plume-Lithosphere Interaction and Polybaric Melt Hybridization. Journal of Petrology, 38, 1359-1390. http://dx.doi.org/10.1093/petroj/38.10.1359 
[3] White, R.S., Spence, G.D., Fowler, S.R., McKenzie, D.P., Westbrook, G.K. and Bowen, A.N. (1989) Magmatism and Rifted Continental Margin. Nature, 330, 439-444. http://dx.doi.org/10.1038/330439a0

[4] White, R.S. and McKenzie, D.P. (1989) Magmatism and Rift Zones: The Generation of Volcanic Continental Margins and Flood Basalts. Journal of Geophysical Research, 96, 7685-7729. http://dx.doi.org/10.1029/JB094iB06p07685

[5] Mattash, M.A., Pinarelli, L., Vaselli, O., Minissale, A., Al-Kadasi, M., Shawki, M.N. and Tassi, F. (2013) Continental Flood Basalts and Rifting: Geochemistry of Cenozoic Yemen Volcanic Province. International Journal of Geosciences, 4, 1459-1466. http://dx.doi.org/10.4236/ijg.2013.410143

[6] Heikal, M.Th.S., Lebda, E.M., Orihashi, Y. and Habtoor, A. (2014) Petrogenetic Evolution of Basaltic Lavas from Balhaf-Bir Ali Plio-Quaternary Volcanic Field, Arabian Sea, Republic of Yemen. Arabian Journal of Geosciences, 7, 69-86. http://dx.doi.org/10.1007/s12517-012-0726-z

[7] Eraky, M.R. (2012) Electrical Conductivity of Cobalt-Titanium Substituted SrCaM Hexaferrites. Journal of Magnetism and Magnetic Materials, 324, 1034-1039. http://dx.doi.org/10.1016/j.jmmm.2011.10.021

[8] Purushotham, Y., Kishan, P., Kumar, N. and Reddy, P.V. (1995) Electrical Transport Properties of Germanium-Substituted Lithium Ferrites. Materials Letters, 22, 47-54. http://dx.doi.org/10.1016/0167-577X(94)00224-X

[9] Klinger, M.I. (1975) Two-Phase Polaron Model of Conduction in Magnetite-Like Solids. Journal of Physics C: Solid State Physics, 8, 3595. http://dx.doi.org/10.1088/0022-3719/8/21/029

[10] Elliott, S.R. (1987) A.C. Conduction in Amorphous Chalcogenide and Pnictide Semiconductors. Advances in Physics, 36, 135. http://dx.doi.org/10.1080/00018738700101971

[11] Pike, G.F. (1972) AC Conductivity of Scandium Oxide and a New Hopping Model for Conductivity. Physical Review B, 6, 1572-1580. http://dx.doi.org/10.1103/PhysRevB.6.1572

[12] Koops, C.G. (1951) On the Dispersion of Resistivity and Dielectric Constant of Some Semiconductors at Audio Frequencies. Physical Review, 83, 121-124. http://dx.doi.org/10.1103/PhysRev.83.121

[13] Fayek, M.K., Elnimr, M.K., Sayedahmed, F., Ata-Allah, S.S. and Kaiser, M. (2000) Relaxation Characteristics of $\mathrm{NiGa}_{\mathrm{x}} \mathrm{Fe}_{2-\mathrm{x}} \mathrm{O}_{4}$. Solid State Communications, 115, 109-113. http://dx.doi.org/10.1016/S0038-1098(00)00156-3

[14] Ravinder, D. and Latha, K. (1999) Dielectric Behaviour of Mixed Mg-Zn Ferrites at Low Frequencies. Materials Letters, 41, 247-253. http://dx.doi.org/10.1016/S0167-577X(99)00138-X

[15] Eraky, M.R. (2015) Abnormal Dielectric Behavior in Ti-Ni Spinel Ferrite. International Journal of Scientific Engineering and Research (IJSER), 3, 73-78. 